\title{
Prediction equations to estimate the demand of energy and crude protein for maintenance, gain and egg production for laying Japanese quails ${ }^{1}$
}

\section{José Jordão Filho², José Humberto Vilar da Silva ${ }^{3}$, Fernando Guilherme Perazzo Costa 4 , Nilva Kazue Sakomura ${ }^{5}$, Cidinei Trajano Silva ${ }^{6}$, Nalberlania Alves Chagas ${ }^{7}$}

\footnotetext{
1 Projeto financiado pelo CNPq.

2 Doutorado Integrado em Zootecnia, CCA/UFPB, Areia - PB; DAP/CCHSA/UFPB, Bananeiras - PB.

3 PDIZ/CCA/UFPB, Areia - PB and PPGTA/CCHSA/UFPB, Bananeiras - PB. Pesquisador CNPq-1C.

${ }^{4}$ PDIZ/CCA/UFPB, Areia - PB.

${ }^{5}$ Departamento de Zootecnia da FCAV-UNESP-Jaboticabal-SP.

${ }^{6}$ Mestrado em Zootecnia, CCA/UFPB, Areia - PB.

${ }^{7}$ Curso de Licenciatura em Ciências Agrárias - CCHSA/UFPB. Pesquisador PIBIC - CNPq/UFPB.
}

\begin{abstract}
The study was conducted to estimate requirements of energy and crude protein for maintenance, weight gain and egg production of Japanese quails in the period of 67 to 107 days of age. Two experiments were performed: one, to determine the requirements for maintenance of protein, and the other, for energy. Experiments were conducted in a completely randomized design with four dietary levels of offer and four replicates of six birds. The diets offered were: ad libitum (100\%), $75 \%$, 50\%, and 25\% consumption ad libitum (below maintenance). The methodology used to estimate the demand for maintenance was the comparative slaughter. For estimation of the requirement for weight gain, eight groups of 15 quails were reared separately, fed ad libitum and housed under $22{ }^{\circ} \mathrm{C}$ controlled temperature. From these poultry, three groups were slaughtered at $5,10,15,20,25,30,35$ and 40 days of the trial. The requirement for egg production was obtained by taking the ratio of energy content, egg protein, efficiency of energy use and protein for egg production. Prediction equations that estimate maintenance requirement, weight gain and egg production in energy and crude protein of Japanese quail include: metabolizable energy $(\mathrm{kcal} /$ bird $/$ day $)=92.34 *$ body weight ${ }^{0.75}+6.23 *$ weight gain $+4.19 *$ egg mass; crude protein $(\mathrm{g} / \mathrm{bird} / \mathrm{day})=$ $6.71 *$ body weight ${ }^{0.75}+0.615 *$ weight gain $+0.258 *$ egg mass.
\end{abstract}

Key Words: egg production, energy, modeling, protein

\section{Introduction}

Energy and protein are the main nutrients considered in feed formulation. Energy regulates food intake and, since quails have relatively higher feed intake compared with chickens (Silva \& Costa, 2009), supply of diets with inadequate energy level can change consumption and reduce these animals' performance.

Foods rich in crude protein have greater share on the cost, since they represent about $25 \%$ of total expenditures. Therefore, the best level of dietary protein for efficiency on production and profit should be determined. Feed formulation for quails is still made based on foreign tables for nutritional specifications, with estimated levels for quite some time and some adaptations of bird species, or studies on dose-response methodology. There are a number of recommendations for energy determined by prediction models for pullets (Albino et al., 1994), layers (Sakomura et al., 2005), breeders at growth (Sakomura et al., 2003) and laying (Rabello et al., 2004) phases, broilers (Longo et al., 2006) and quails (Silva et al., 2004ab) during growth. Similarly, there are several recommendations for protein determined by prediction models for pullets (Basaglia et al., 1998), breeders (Rabello et al., 2002), broilers (Longo et al., 2001) and even quails (Silva et al. 2004ab) during growth; however, there are no reports of experiments with quail on egg production.

Prediction equations can be important tools in determining the nutritional requirements of quails by fractioning the estimate on maintenance, gain, and especially requirement and efficiency of egg production. This allows performing more elaborate feeding programs in the nutrient profile and minimum feed cost. However, few studies use this methodology since it is very laborious and costly, requiring expensive equipment and researcher care with samples.

Obtaining prediction models from poultry growing requirements is simpler than for laying poultry, since in addition to maintenance and gain, mass production of eggs must be considered (Zhang \& Coon, 1994). This 
study aimed to determine the requirements of energy and crude protein for maintenance, weight gain and egg production and thus develop models to predict Japanese quails’ requirements for full egg production.

\section{Material and Methods}

The experiment was conducted at the Laboratório de Pesquisa em Nutrição de Aves - LPNA at the Centro de Ciências Humanas, Sociais e Agrárias - UFPB, located in the municipality of Bananeiras, Paraíba, Brazil.

Laying Japanese quails were studied in the period from 67 to 107 days of age in order to develop prediction equations for energy and protein to estimate maintenance, weight gain and egg production.

The estimated requirement of energy and crude protein of Japanese quails for maintenance was determined with testing for 22 days - with seven days of adaptation to food and facilities and 15 days of data collection. Quails were housed in galvanized wire cages measuring $33 \times 33 \times 16 \mathrm{~cm}$, located in climate room with controlled temperature $\left(22.6 \pm 0.6{ }^{\circ} \mathrm{C}\right)$ and humidity $(72.6 \pm 1.2 \%)$. Ninety-six female Japanese quails were distributed in four feed levels and four replicates of six birds, arranged in a randomized design. Feed levels were as follows: level $1=$ ad libitum consumption (100\%), level $2=75 \%$, level $3=50 \%$ and level $4=25 \%$ ad libitum consumption. The level of $25 \%$ ad libitum consumption determined according to data observed by the prediction model of Silva et al. (2004ab) for nutrient intake was below the maintenance. Feed was formulated based on corn and soybean meal (Table 1), taking into account the suggestions of the Table for Quails’ Nutritional Requirements (Silva \& Costa, 2009).

The requirement for maintenance of quails in energy and crude protein was estimated by the comparative slaughter method. For this, a group of 100 quails of each strain was slaughtered at the beginning, at 67 days of age (reference slaughter) and all poultry left in the plots were slaughtered at the end of the experiment at 107 days of age, having as premise the theory that composition of a poultry group represents the body composition of the entire population (Wolynetz \& Sibbald, 1987). The reference group was chosen based on the average weight of all quails at 67 days old.

Before slaughter, poultry were subjected to feed starvation for 24 hours, weighed and finally slaughtered by cervical dislocation, avoiding loss of blood and feathers to allow evaluating nutrients deposition and energy in the empty body.
Table 1 - Food and nutritional composition of the experimental diet $^{1}$

\begin{tabular}{lc}
\hline Ingredient & Natural matter (\%) \\
\hline Corn & 56.845 \\
Soybean meal & 33.616 \\
Limestone & 5.414 \\
Dicalcium phosphate & 1.319 \\
Soybean oil & 1.957 \\
Salt & 0.521 \\
DL-methionine & 0.114 \\
L-threonine & 0.004 \\
Vitamin premix & 0.100 \\
Mineral premix ${ }^{3}$ & 0.050 \\
Choline chloride & 0.050 \\
Antioxidant ${ }^{4}$ & 0.010 \\
Chemical composition & \\
Crude protein (\%) & 20.000 \\
AMEn (kcal/kg) & 2.900 \\
Calcium (\%) & 2.500 \\
Available phosphorus (\%) & 0.350 \\
Arginine (\%) & 1.347 \\
Lysine (\%) & 1.076 \\
Methionine (\%) & 0.428 \\
Methionine + cystine (\%) & 0.750 \\
Threonine (\%) & 0.790 \\
Tryptophan (\%) & 0.252 \\
Valine (\%) & 0.943 \\
Sodium (\%) & 0.230 \\
Potassium (\%) & 0.798 \\
Chlorine (\%) & 0.356 \\
\hline Recom &
\end{tabular}

${ }^{1}$ Recommendations of Silva \& Costa (2009).

2 Composition/kg of product: vit. A - 10,000,000 IU, vit. D3 - 2,500,0000 IU, vit. E - 15,000 mg, vit. K - 2,000 mg, vit. B1 - 2,000 mg, vit. B2 - 4,000 mg, vit. B6 4,000 mg, vit. B12 - 15,000 mg, vit. C - 50,000 mg, Niacin - 30,000 mg, Biotin $60 \mathrm{mg}$, folic acid - $500 \mathrm{mg}$, pantothenic acid - 16,000 mg; BHT - $125 \mathrm{mg}$.

${ }^{3}$ Composition/kg of product: zinc - 110,000 mg; selenium - $360 \mathrm{mg}$, iodine 1,400 mg, copper - 20,000 mg, manganese - 156,000 mg; Iron - 96,000 mg.

${ }^{4}$ Butylated hydroxy toluene.

Poultry's empty bodies were identified and stored in freezer, and then ground in a cutter-type meat grinder three consecutive times to allow withdrawal of representative samples for analysis. Body samples were weighed and placed in forced ventilation oven at $55{ }^{\circ} \mathrm{C}$ for 72 hours, approximately, for pre-drying. Subsequently, samples were ground in the cutter again for two consecutive times and once in a Willey mill type, carried to the laboratory for analytical determinations, as recommended by Silva \& Queiroz (2002).

For determination of dry matter content, samples were oven-dried $\left(105^{\circ} \mathrm{C}\right)$ for 4 hours. Crude protein values of samples were obtained by the Kjeldahl method and ether extract was determined via fat extraction with hexane in Soxhlet system. Mineral matter was determined after firing in oven at $600{ }^{\circ} \mathrm{C}$ for 4 hours. Crude energy was determined by Parr type adiabatic bomb calorimeter. Energy and protein retained in poultry's body from each plot were calculated by the difference between the amount of energy and protein in the empty body of poultry slaughtered at the end of the 
experiment and the amount present in quails' carcass from the slaughter-reference group.

Requirement for maintenance was estimated by linear regression of energy and/or protein trapped in the empty body in relation to consumptions of energy and protein; the line intercept with $\mathrm{X}$ axis the estimate for maintenance, while the slope, in other words, regression coefficient (parameter "b"), indicated the efficiency of energy use and protein for gain. Net energy requirement for maintenance was estimated by exponential regression of heat production as a function of energy intake (Farrell, 1974), when extrapolated to zero energy consumption. Heat production was estimated by the difference between consumption and energy retention.

Parallel to the maintenance test, 120 quails were reared and distributed into eight groups of 15 poultry fed ad libitum and housed at $22.4 \pm 0.6^{\circ} \mathrm{C}$ controlled temperature for determination of energy and protein requirements for gain. From these birds, a group in turn was slaughtered at 5, 10, 15, 20, 25, 30, 35 and 40 days of experiment. Every five days, feed intake, poultry weight and weight gain were recorded for each subgroup. Processing of poultry's empty body was similar to that presented in the experiment for maintenance, respecting the same methodology.

Net requirement for body gain was estimated by regression of energy and/or body protein as a function of empty body's weight, with parameter "b" as the requirement in its self kcal/g metabolizable energy and g/g crude protein for weight gain. Meanwhile, the gain dietary requirement was calculated by the ratio between gain net requirement and use efficiency determined in the test for maintenance, respectively, for energy and protein.

For determination of the requirement of energy and protein for egg production, 54 Japanese quails were housed and distributed into nine groups of six birds each receiving the same food ad libitum (Table 1). The demand for energy and protein for egg production was obtained by the ratio between the average level of energy and/or protein in eggs and use efficiency (Rabello et al. 2002; Sakomura et al., 2005). The average levels of energy and/or crude protein of eggs were determined by proximal analysis of these components in all eggs collected in the plots and analyzed every five days. The value of energy and/or crude protein of eggs (shell + contents) were determined by the product of egg mass vs. average content of energy and/or protein in eggs. The use efficiency of metabolizable energy and crude protein for egg production was calculated based on formulas presented in previous studies (Sakomura et al. 2005; Rabello et al., 2002): use efficiency (\%) = energy/protein retained in the egg $\div$ [energy/protein consumption - (energy demand/protein for maintenance + energy requirement/ protein to gain)].

\section{Results and Discussion}

During the Japanese quails' performance (Table 2), there was a decrease in features as the supply of basal diet was reduced, according to results observed in pullets (Albino et al., 1994), young quails (Silva et al., 2004a) and quails at growth (Silva et al., 2004b).

Reduction in quails' performance with reduced food supply became more pronounced with quails' weight loss from the $75 \%$ level, probably because the nutrient intake was insufficient to meet the maintenance requirement plus production. According to Silva et al. (2004b), maintenance is the condition of the body's nutritional status, with no loss or gain of tissue or matter translocation in the body.

Quails' weight loss receiving 75, 50 and 25\% feed was therefore different from the result observed in growing quails (Silva et al., 2004ab) and this indicates that the maintenance of egg production is a priority for quail's body, even if it involves the mobilization of nutrients deposited in the body during growth and subsequent weight loss. Quails fed on 75\% feed level ad libitum showed weight loss, but kept weight and egg production close to the results obtained with the normal food supply, although egg mass reduced by around $13 \%$ at observed values in ad libitum feeding. Due to the low feed intake observed in severe restriction levels, quails started to drastically decrease egg production from the third level of feed supply (75\% ad libitum), behavior similar to that reported by Rabello et al. (2004) in breeding broilers.

Variation in egg production caused by food restriction is attributed to the variable's being dependent on poultry's

Table 2 - Performance of Japanese quails under different levels of feed supply

\begin{tabular}{ccccccc}
\hline $\begin{array}{c}\text { Feed } \\
\text { supply (\%) }\end{array}$ & $\begin{array}{c}\text { Final } \\
\text { weight }(\mathrm{g})\end{array}$ & $\begin{array}{c}\text { Weight } \\
\text { variation (g/day) }\end{array}$ & $\begin{array}{c}\text { Feed } \\
\text { consumption (g/day) }\end{array}$ & $\begin{array}{c}\text { Eggs } \\
\text { weight (g) }\end{array}$ & $\begin{array}{c}\text { Eggs } \\
\text { production }(\%)\end{array}$ & $\begin{array}{c}\text { Egg } \\
\text { mass (g) }\end{array}$ \\
\hline 100 & $163.35 \pm 3.3$ & $0.38 \pm 0.2$ & $26.11 \pm 1.1$ & $11.67 \pm 0.3$ & $75.43 \pm 8.5$ & $8.80 \pm 1.1$ \\
75 & $144.72 \pm 3.1$ & $-0.81 \pm 0.5$ & $19.77 \pm 1.0$ & $10.96 \pm 0.4$ & $69.95 \pm 5.9$ & $7.66 \pm 0.6$ \\
50 & $119.56 \pm 4.5$ & $-2.46 \pm 0.2$ & $13.44 \pm 1.0$ & $10.64 \pm 0.5$ & $34.87 \pm 5.2$ & $3.71 \pm 0.7$ \\
25 & $95.24 \pm 1.0$ & $-4.80 \pm 0.2$ & $6.58 \pm 0.5$ & $5.42 \pm 1.0$ & $20.05 \pm 1.8$ & $1.09 \pm 0.3$ \\
\hline
\end{tabular}


protein consumption (Pinto et al., 2002). This correlation effect has been observed between protein intake and egg weight, since $5.22 \mathrm{~g} / \mathrm{bird} /$ day/ of protein intake and $11.67 \mathrm{~g}$ of egg weight were observed in this research for quails fed ad libitum, while Freitas et al. (2005) found 4.85 g/bird/day and $10.37 \mathrm{~g}$ eggs in hens fed ad libitum on $20 \%$ crude protein. Variation in results among studies may be explained by many factors, including balance and availability of amino acids. Linear increase in egg weight with increasing levels of protein in the diet of Japanese quails was observed by Pinto et al. (2002). Therefore, weight and egg mass decreased with food restriction increase due to lower protein intake. There was decrease in consumption and energy and protein retentions and heat production (Table 3) as basal diet supply was reduced in agreement with previous studies on chickens (Albino et al., 1994), young quails (Silva et al., 2004a) and growing quails (Silva et al., 2004b). Decreased consumption, decreased retention and heat production of quails was greater at the more severe restriction levels of consumption, indicating that the nutrients intake was not sufficient to meet the requirements for maintenance and egg production.

From consumption and energy retention in the empty body and eggs of quails (Table 3 ), the regression equation estimate $92.34 \mathrm{kcal} / \mathrm{kg}^{0.75} /$ day maintenance requirement (Figure 1) and the net requirement for $62.07 \mathrm{kcal} / \mathrm{kg}^{0.75} / \mathrm{day}$ energy maintenance (Figure 2) were elaborated. This estimate on maintenance energy requirement for Japanese quails on the egg laying peak was slightly higher than the $91.48 \mathrm{kcal} / \mathrm{kg}^{0.5} /$ day estimated by Silva et al. (2004b) for Japanese quails and lower than the $111.98 \mathrm{kcal} / \mathrm{kg}^{0.75} /$ day found by Sakomura et al. (2005) for laying hens. On the other hand, energy for maintenance was above $87.76 \mathrm{kcal} / \mathrm{kg}^{0.75} / \mathrm{day}$ determined with breeders by Spratt et al. (1990) using the calorimetry technique.

In addition to environmental factors such as temperature, stocking density, diet composition and species, obtainment methods have different estimates. Typically,

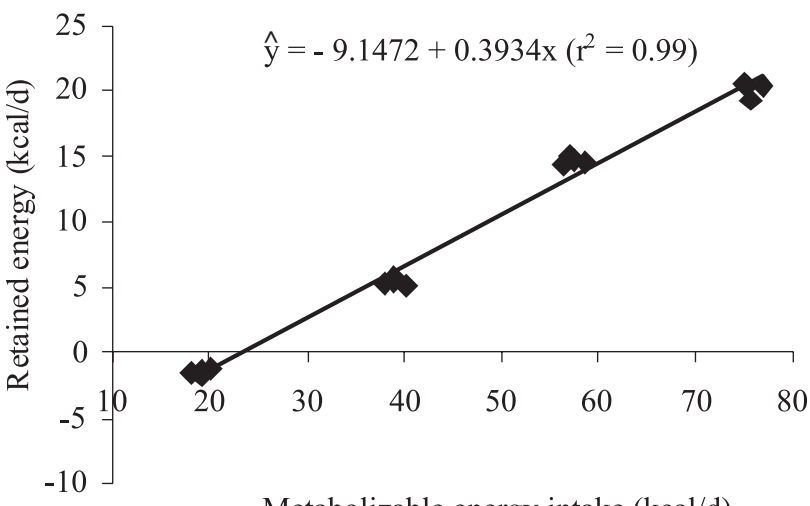

Metabolizable energy intake ( $\mathrm{kcal} / \mathrm{d})$

Figure 1- Retained energy as a function of metabolizable energy intake of Japanese quails from 67 to 107 days old.

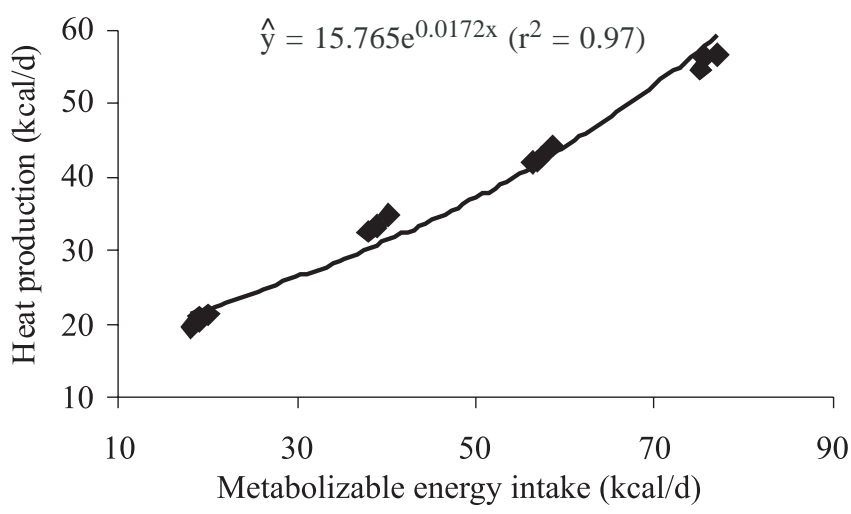

Figure 2 - Exponential equation of heat production as a function of metabolizable energy intake of Japanese quails from 67 to 107 days old.

studies on energy have been determined in respiratory chambers, calorimetry, carbon and nitrogen balance and comparative slaughter (Sakomura \& Rostagno, 2007). According to Fuller et al. (1983), heat production values obtained by calorimetry and comparative slaughter technique differ from 3 to $12 \%$ and were lower when obtained by calorimetry.

The energy retained during the egg laying peak in quails was $39 \%$ of that intake, higher than the $22 \%$ use

Table 3 - Consumption and retention of protein and energy and heat production of Japanese quails at different levels of food supply

\begin{tabular}{|c|c|c|c|c|c|}
\hline \multirow[b]{2}{*}{ Feed supply } & \multicolumn{3}{|c|}{ Energy } & \multicolumn{2}{|c|}{ Protein } \\
\hline & $\begin{array}{c}\text { Energy consumption } \\
\text { (kcal/day) }\end{array}$ & $\begin{array}{c}\text { Retained } \\
\text { energy }(k c a l / d a y)^{1}\end{array}$ & $\begin{array}{l}\text { Heat production } \\
\text { (kcal/day) }\end{array}$ & $\begin{array}{c}\text { Protein } \\
\text { consumption (g/day) }\end{array}$ & $\begin{array}{c}\text { Retained } \\
\text { protein }(\mathrm{g} / \text { day })^{2}\end{array}$ \\
\hline $100 \%$ (ad libitum) & $75.71 \pm 2.2$ & $20.13 \pm 0.49$ & $55.58 \pm 0.96$ & $5.22 \pm 0.2$ & $1.217 \pm 0.01$ \\
\hline $75 \%$ & $57.34 \pm 3.0$ & $14.61 \pm 0.23$ & $42.73 \pm 0.91$ & $3.95 \pm 0.2$ & $1.009 \pm 0.02$ \\
\hline $50 \%$ & $38.97 \pm 2.2$ & $5.38 \pm 0.21$ & $33.59 \pm 0.86$ & $2.69 \pm 0.2$ & $0.400 \pm 0.02$ \\
\hline $25 \%$ & $19.09 \pm 0.9$ & $-1.52 \pm 0.23$ & $20.66 \pm 0.70$ & $1.32 \pm 0.1$ & $-0.219 \pm 0.01$ \\
\hline
\end{tabular}

${ }^{1}$ The following amounts of retained energy in eggs were considered: 14.42, 11.32, 5.92 and $1.86 \mathrm{kcal} / \mathrm{g}$ egg for 100 , 75, 50 and 25\% ad libitum feeding, respectively.

2 The following amounts of protein retained in eggs were considered: $0.98,0.86,0.44$ and 0.12 g/g egg 100,75 , 50 and $25 \%$ ad libitum feeding, respectively. 
efficiency found by Silva et al. (2004b) and the 23\% obtained by Jordão Filho et al. (2011) for growing Japanese quails. However, the value was below the $65 \%$ used by Sakomura et al. (2005) in laying hens.

The net requirement for maintenance of metabolizable energy determined by the exponential equation of heat production as a function of metabolizable energy intake was $62.07 \mathrm{kcal} / \mathrm{kg}^{0.75} /$ day and provided $69 \%$ maintenance efficiency (Figure 2). The estimate is similar to the 61.17 $\mathrm{kcal} / \mathrm{kg}^{0.75} /$ day requirement and $72 \%$ use efficiency for maintenance determined by Silva et al. (2004b) with Japanese quails from 15 to 32 days old. From consumptions and retentions of protein in empty body and eggs (Table 3 ) of quails, the regression equation that estimated $6.71 \mathrm{~g} / \mathrm{kg}^{0.75} / \mathrm{day}$ crude protein for maintenance (Figure 3) was elaborated, considering $0.254 \mathrm{~kg}^{0.75}$ units of metabolic weight.

Protein requirement for maintenance $\left(6.71 \mathrm{~g} / \mathrm{kg}^{0.75} /\right.$ day protein) was above the estimated values in growing Japanese quails (Silva et al., 2004b). Estimate was also superior to requirements of 1.94 and $2.28 \mathrm{~g} / \mathrm{kg}^{0.75} /$ day protein for laying hens (Sakomura et al., 2002) and breeding layins hens (Rabello et al., 2002) in egg production, respectively, using the technique of nitrogen balance. Divergent results can be attributed to multiple factors, but the main ones were genotype, stage of formation and experimental methodology. Silva et al. (2010) found estimates for European quails different from the requirement obtained by Silva et al. (2004b) with Japanese quails from 15 to 32 days of age (4.86 versus $4.75 \mathrm{~g} / \mathrm{kg}^{0.75} /$ day) housed in the floor. Filardi et al. (2000), working with growing breeding pullets, determined different estimate values for protein maintenance between the comparative slaughter methodology and the technique of nitrogen balance ( 3.75 vs. $2.02 \mathrm{~g} / \mathrm{kg}^{0.75} /$ day), indicating differences in the experimental methodology.

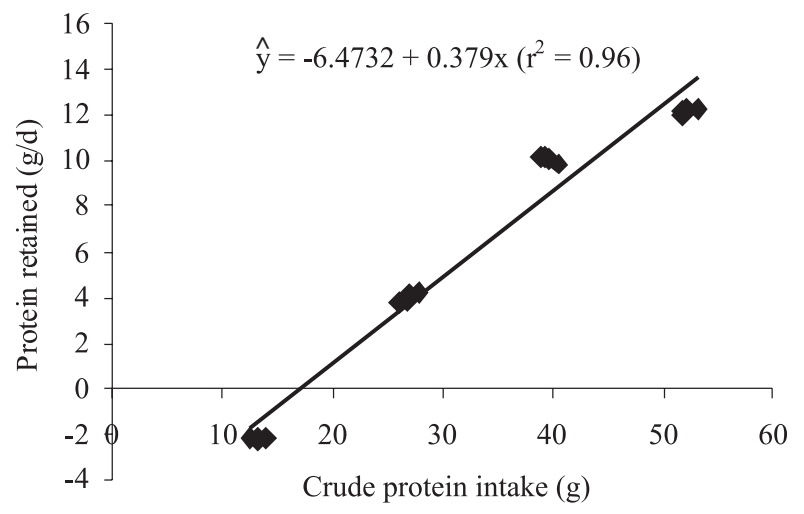

Figure 3 - Crude protein retained depending on the protein intake of Japanese quails from 67 to 107 days old.
Protein estimation in the present study, compared with the estimated requirement on growth (Silva et al., 2004b), perfectly denotes the influence of formation stage on nutrition due to the poultry development's being marked by physiological determinants, such as bone and muscle formations, warping, reproductive system formation and egg production maintenance. On the other hand, the use efficiency (38\%) found for crude protein retained as a function of that ingested was similar to that obtained by Sakomura et al. (2002) in laying hens. The value means that for every gram of protein consumed, $380 \mathrm{mg}$ of crude protein were retained in the carcass and quail's egg. The efficiency of protein deposition for maintenance (38\%) was above the $23 \%$ obtained in Japanese growing quails, suggesting that quails at laying use maintenance protein with more efficiency due to increased turnover of poultry in egg production.

Weight and chemical and energy composition of quails' empty body showed variation over the rearing age (Table 4). Protein content in the empty body over the slaughters had little variation, although the water content tended to decrease, while fat tended to increase with advancing age of quails. Results confirm previous studies, where the advancing age of poultry causes reduction in the water percentage and increase in fat content (Marks, 1993; Rabello et al., 2002; Silva et al. 2004b), which is common for maturity (Bennett \& Leeson, 1990). Literature has reported a negative correlation between fat and water contents in the carcass of broilers (Bartov \& Plavnik, 1998), growing pullets (Martin et al., 1994; Neme et al., 2006) and laying hens (Chwalibog, 1992).

The linear regression equation of the retained energy as a function of empty body weight estimated a $2.43 \mathrm{kcal} / \mathrm{g}$ gain net requirement for energy (Figure 4 ) and $0.23 \mathrm{~g} / \mathrm{g}$ for protein (Figure 5). The estimate is higher than the $2.07 \mathrm{kcal} / \mathrm{g}$ gain estimated in Japanese quails (Jordão Filho et al., 2011); however, it was below the $4.34 \mathrm{kcal} / \mathrm{g}$ gain required by layers (Sakomura et al., 2005).

Discrepancy of results between this research and that determined by Jordão Filho et al. (2011) may be explained by the higher body fat content of poultry at laying in relation to growing quails, since fat content increases with poultry age and directly affects body energy availability.

Considering the energy use efficiency required for 39\% net gain (Figure 1), the dietary energy requirement of 6.23 $\mathrm{kcal} / \mathrm{g}$ weight gain (Figure 4) is estimated, similarly to the $6.68 \mathrm{kcal} / \mathrm{g}$ estimated by Sakomura et al. (2005), for laying hens. Even though, according to Scott et al. (1982), values should be viewed with caution, since the gain depends on body composition, which differs between species. 
The net estimate of protein gain obtained in this study is higher than that estimated by Silva et al. (2004ab) of 0.190 and $0.194 \mathrm{~g} / \mathrm{g}$ in Japanese quails from 1 to 12 and 15 to 32 days old. This difference may be related to increased protein turnover in the quail's body in egg production as compared with growing quails. The profile of amino acids mobilized from body protein can lead to greater loss of nitrogen in the form of uric acid from body source, requiring higher nitrogen content in feed per gram of weight gain. This result is confirmed by low values of gain protein requirement estimated in growing pullets (Albino et al. 1994; Basaglia et al., 1998) compared with laying hens in egg production (Sakomura et al., 2002). Considering the 0.233 -g gain net requirement (Figure 5) and 38\% use efficiency of protein requirement for net gain (Figure 3), a 0.615-g/g weight gain for dietary protein requirement was estimated.

The nutritional components of Japanese quail's eggs during the period of analysis (Table 5) showed little variation, except for levels of mineral matter, similar to those observed in laying hens (Sakomura et al., 2002) and breeders (Rabello et al., 2002). With poultry’s advancing age, there

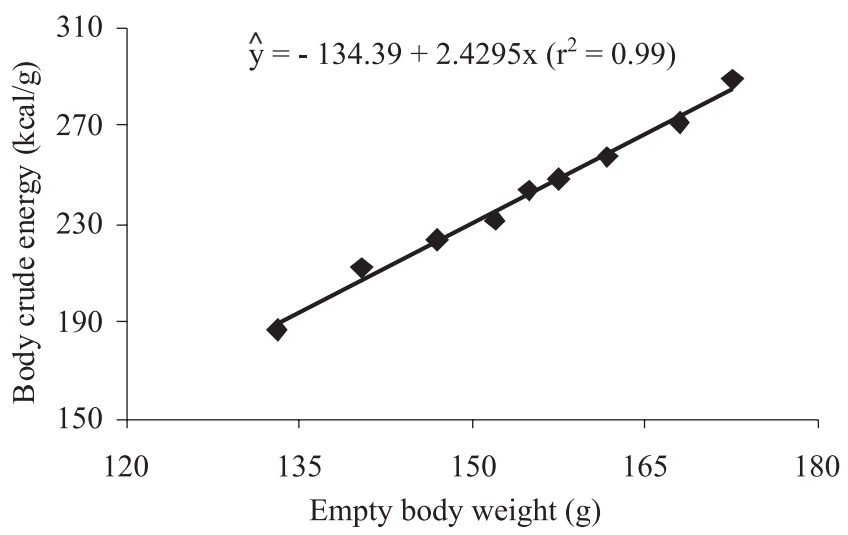

Figure 4 - Body crude energy content of Japanese quails as a function of empty body weight when net requirement for gain was $2.43 \mathrm{kcal} / \mathrm{g}$. is increase in egg weight without a proper monitoring of bark percentage, which may explain the lower values of mineral matter when poultry became older.

The average protein level of quail eggs (11.1\%) was similar to that found by Sakomura et al. (2002) in laying hens' eggs (11.4\%) but lower than the $12.2 \%$ protein found in breeding broilers' eggs (Rabello et al., 2002). On the other hand, the 1.55-kcal/g crude energy value/g egg differed from that observed by Sakomura et al. (2005), of $1.49 \mathrm{kcal} / \mathrm{g}$.

Considering the $1.55-\mathrm{kcal} / \mathrm{g}$ average crude energy content of eggs (Table 5) and the 37\% use efficiency of energy for egg production (Table 6), a 4.19-kcal/g dietary requirement of metabolizable energy per gram of egg produced was determined.

Considering the $1.55-\mathrm{kcal} / \mathrm{g}$ egg produced by the $37 \%$ efficiency, we have 4.19-kcal EM/g egg produced, a result higher than the 2.40-kcal EM/g egg production in laying hens (Sakomura et al., 2005), indicating that quails require more energy to produce 1-g eggs than laying hens, because of the lower use efficiency (37\%) compared with that used by Sakomura et al. (2005), of 62\%.

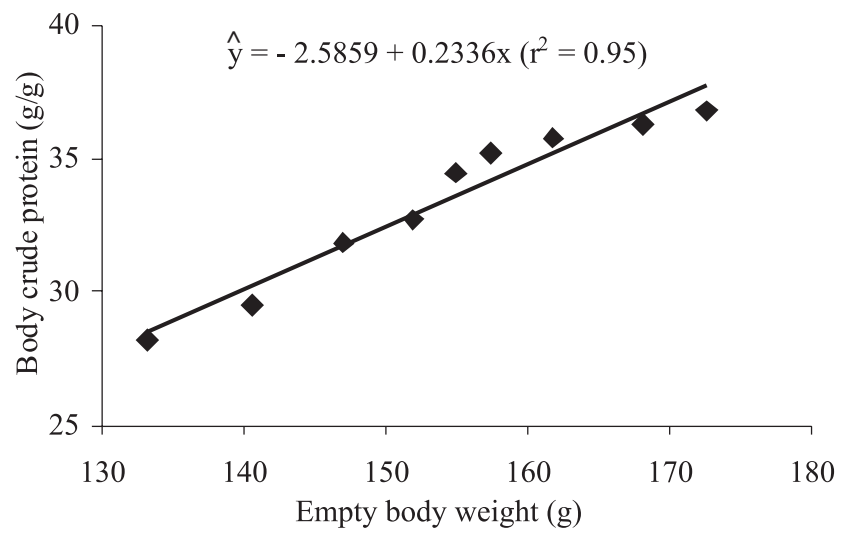

Figure 5 - Body crude protein content of Japanese quails as a function of empty body weight when net requirement for gain was $0.234 \mathrm{~g} / \mathrm{g}$.

Table 4 - Weight, chemical and energy composition of Japanese quails' empty body as a function of age ${ }^{1}$

\begin{tabular}{|c|c|c|c|c|c|c|c|c|}
\hline $\begin{array}{l}\text { Age } \\
\text { (days) }\end{array}$ & $\begin{array}{l}\text { Empty body's } \\
\text { weight (g) }\end{array}$ & $\begin{array}{c}\text { Dry } \\
\text { matter (\%) }\end{array}$ & $\begin{array}{c}\text { Mineral } \\
\text { matter (\%) }\end{array}$ & $\begin{array}{l}\text { Crude } \\
\text { fat (\%) }\end{array}$ & $\begin{array}{c}\text { Crude } \\
\text { protein (\%) }\end{array}$ & $\begin{array}{c}\text { Crude } \\
\text { energy (kcal) }\end{array}$ & $\begin{array}{l}\text { Body energy } \\
\text { (kcal/g) }^{1}\end{array}$ & $\begin{array}{c}\text { Body } \\
\text { protein }(\mathrm{g})^{2}\end{array}$ \\
\hline 67 & $133.14 \pm 0.6$ & $28.61 \pm 0.1$ & $3.40 \pm 0.1$ & $3.86 \pm 0.1$ & $21.20 \pm 0.3$ & $1402.23 \pm 56$ & $186.69 \pm 11$ & $28.23 \pm 0.6$ \\
\hline 72 & $140.52 \pm 1.4$ & $28.64 \pm 0.1$ & $3.42 \pm 0.1$ & $4.88 \pm 0.2$ & $21.03 \pm 0.4$ & $1509.36 \pm 78$ & $212.10 \pm 10$ & $29.55 \pm 0.7$ \\
\hline 82 & $151.97 \pm 1.5$ & $30.62 \pm 0.1$ & $3.00 \pm 0.1$ & $6.00 \pm 0.1$ & $21.54 \pm 0.4$ & $1520.30 \pm 60$ & $231.04 \pm 10$ & $32.73 \pm 0.7$ \\
\hline 87 & $154.93 \pm 1.3$ & $32.37 \pm 0.4$ & $3.40 \pm 0.1$ & $7.14 \pm 0.1$ & $22.25 \pm 0.2$ & $1571.18 \pm 68$ & $243.43 \pm 11$ & $4.47 \pm 0.5$ \\
\hline 92 & $157.42 \pm 1.5$ & $32.91 \pm 0.4$ & $3.32 \pm 0.1$ & $7.57 \pm 0.2$ & $22.37 \pm 0.2$ & $1578.76 \pm 68$ & $248.52 \pm 11$ & $35.21 \pm 0.5$ \\
\hline 107 & $172.60 \pm 0.8$ & $30.63 \pm 0.6$ & $3.95 \pm 0.1$ & $7.19 \pm 0.1$ & $21.30 \pm 0.6$ & $1672.43 \pm 64$ & $288.66 \pm 11$ & $36.76 \pm 0.7$ \\
\hline
\end{tabular}

\footnotetext{
${ }^{1}$ Body energy was obtained by the product of crude energy with the empty body weight.
}

${ }^{2}$ Body protein was calculated as the product of crude protein in the empty body weight. 
Dietary protein requirement for egg production was determined by the use efficiency of crude protein of eggs (Table 7). Therefore, use efficiency of protein for egg production was $43 \%$, close to the $46.8 \%$ given by Rabello et al. (2002) in breeding broilers. Considering the $11.11 \%$ crude protein average value, in other words, 0.111 -g crude protein/g egg and 43\% use efficiency, 0.258-g dietary crude protein per gram of egg produced was estimated. This estimate is similar to the 0.262 -g crude protein/g egg produced by breeders (Rabello et al., 2002), but below that determined by Sakomura et al. (2002) in laying hens: 0.301-g crude protein/g egg.

The higher requirement for crude protein/g egg in laying hens can be attributed to the lower protein use efficiency for egg production.

Prediction equations are important tools for fractionating nutritional requirements of quails in maintenance, gain, and especially, requirement and efficiency of egg production, which allows the establishment of more elaborate feeding programs, adjusting the nutrient profile and minimum feed cost.

Table 5 - Chemical and energy composition of Japanese quails' eggs from 67 to 107 days old

\begin{tabular}{lcccccc}
\hline Age (days) & Dry matter $(\%)$ & Water content $(\%)$ & Crude fat $(\%)$ & Mineral matter (\%) & Crude protein (\%) & Crude energy (kcal/g) \\
\hline $67-72$ & $28.65 \pm 0.45$ & $71.35 \pm 0.45$ & $8.87 \pm 0.34$ & $5.19 \pm 0.73$ & $10.85 \pm 0.24$ & $1.504 \pm 0.02$ \\
$72-77$ & $30.19 \pm 0.42$ & $69.81 \pm 0.42$ & $9.28 \pm 0.22$ & $6.11 \pm 1.24$ & $11.39 \pm 0.44$ & $1.596 \pm 0.03$ \\
$77-82$ & $29.89 \pm 0.97$ & $70.11 \pm 0.97$ & $9.42 \pm 0.30$ & $5.14 \pm 0.58$ & $11.21 \pm 0.43$ & $1.568 \pm 0.06$ \\
$82-87$ & $28.87 \pm 0.21$ & $71.13 \pm 0.21$ & $8.84 \pm 0.50$ & $5.21 \pm 1.01$ & $10.85 \pm 0.29$ & $1.548 \pm 0.02$ \\
$87-92$ & $29.63 \pm 0.69$ & $70.37 \pm 0.69$ & $9.07 \pm 0.11$ & $6.38 \pm 0.99$ & $11.10 \pm 0.57$ & $1.560 \pm 0.02$ \\
$92-97$ & $29.12 \pm 0.58$ & $70.88 \pm 0.58$ & $9.10 \pm 0.17$ & $4.40 \pm 0.20$ & $10.74 \pm 0.30$ & $1.557 \pm 0.03$ \\
$97-102$ & $30.48 \pm 0.74$ & $69.52 \pm 0.74$ & $9.05 \pm 0.23$ & $4.94 \pm 0.50$ & $10.87 \pm 0.22$ & $1.565 \pm 0.01$ \\
$102-107$ & $25.36 \pm 1.02$ & $74.64 \pm 1.02$ & $8.76 \pm 0.73$ & $3.69 \pm 0.17$ & $11.77 \pm 0.50$ & $1.523 \pm 0.03$ \\
Mean & $29.02 \pm 1.50$ & $70.98 \pm 1.50$ & $9.05 \pm 0.21$ & $5.32 \pm 0.59$ & $11.11 \pm 0.33$ & $1.550 \pm 0.02$ \\
\hline
\end{tabular}

Table 6 - Energy requirement for maintenance, weight gain and use efficiency of energy for egg production of Japanese quails as a function of age

\begin{tabular}{|c|c|c|c|c|c|c|}
\hline $\begin{array}{c}\text { Age } \\
\text { (days) }\end{array}$ & $\begin{array}{c}\text { Weight } \\
\text { gain (g/day) }\end{array}$ & $\begin{array}{l}\text { Energy consumption } \\
\text { (kcal/day) }\end{array}$ & $\begin{array}{c}\text { Maintenance } \\
\text { requirement (kcal/day) }{ }^{1}\end{array}$ & $\begin{array}{c}\text { Gain requirement } \\
(\mathrm{kcal} / \text { day })^{2}\end{array}$ & $\begin{array}{cl}\text { Egg's } & \text { retained } \\
\text { energy } & \text { (kcal/dia) }\end{array}$ & $\begin{array}{c}\text { Use } \\
\text { efficiency }(\%)^{3}\end{array}$ \\
\hline $67-72$ & 1.48 & 71.20 & 24.30 & 9.22 & 13.74 & 0.36 \\
\hline $72-77$ & 1.28 & 75.75 & 24.97 & 7.97 & 14.46 & 0.34 \\
\hline $82-87$ & 0.59 & 72.30 & 25.51 & 3.68 & 14.97 & 0.35 \\
\hline $87-92$ & 0.50 & 67.60 & 25.43 & 3.12 & 15.12 & 0.39 \\
\hline $92-97$ & 0.87 & 66.87 & 25.91 & 5.42 & 15.63 & 0.44 \\
\hline Mean & 0.99 & 70.60 & 25.32 & 6.15 & 14.69 & 0.37 \\
\hline
\end{tabular}

${ }^{1}$ Energy requirement for maintenance $=92.34 *$ metabolic weight. Average metabolic weight $=0.27$.

2 Energy requirement for gain $=6.23 *$ weight gain.

3 Use efficiency = energy retained in the egg $\div$ [energy consumption - (energy requirement for maintenance + energy requirement for gain)] .

Table 7 - Protein requirement for maintenance, gain and use efficiency of protein for egg production of Japanese quails in relation to age

\begin{tabular}{|c|c|c|c|c|c|c|}
\hline $\begin{array}{l}\text { Age } \\
\text { (days) }\end{array}$ & $\begin{array}{c}\text { Weight } \\
\text { gain (g/day) }\end{array}$ & $\begin{array}{c}\text { Protein consumption } \\
\text { (g/day) }\end{array}$ & $\begin{array}{c}\text { Maintenance } \\
\text { requirement }(\mathrm{g} / \text { day })^{1}\end{array}$ & $\begin{array}{c}\text { Gain requirement } \\
(\mathrm{g} / \mathrm{day})^{2}\end{array}$ & $\begin{array}{l}\text { Egg's retained } \\
\text { protein }(g / \text { dia })\end{array}$ & $\begin{array}{c}\text { Use } \\
\text { efficiency }(\%)^{3}\end{array}$ \\
\hline $67-72$ & 1.48 & 4.91 & 1.77 & 0.90 & 0.99 & 0.44 \\
\hline $72-77$ & 1.28 & 5.22 & 1.81 & 0.78 & 1.03 & 0.39 \\
\hline $77-82$ & 1.01 & 4.31 & 1.85 & 0.62 & 1.11 & 0.49 \\
\hline $82-87$ & 0.59 & 4.99 & 1.85 & 0.36 & 1.05 & 0.38 \\
\hline $87-92$ & 0.50 & 4.66 & 1.85 & 0.31 & 1.08 & 0.43 \\
\hline $92-97$ & 0.87 & 4.61 & 1.88 & 0.53 & 1.08 & 0.49 \\
\hline $97-102$ & 1.26 & 5.69 & 1.84 & 0.77 & 1.03 & 0.34 \\
\hline $102-107$ & 0.91 & 4.56 & 1.86 & 0.56 & 1.03 & 0.48 \\
\hline Mean & 0.99 & 4.87 & 1.84 & 0.60 & 1.05 & 0.43 \\
\hline
\end{tabular}

${ }^{1}$ Protein requirement for maintenance $=6.71 *$ metabolic weight. Average metabolic weight $=0.27$.

2 Protein requirement for gain $=0.615^{*}$ weight gain.

3 Use efficiency $=$ retained protein in the egg $\div$ [protein intake - (protein requirement for maintenance + protein requirement for gain)]. 


\section{Conclusions}

Prediction equations that estimate requirements for maintenance, gain and egg production in energy and crude protein of Japanese quails are: metabolizable energy $(\mathrm{kcal} /$ bird/day $)=92.34 *$ Body weight ${ }^{0.75}+6.23 *$ weight gain $+4.19 *$ egg mass; and crude protein $(\mathrm{g} / \mathrm{bird} /$ day $)=6.71$ * body weight ${ }^{0.75}+0.615 *$ weight gain $+0.258 *$ egg mass.

\section{Acknowledgements}

The authors would like to thank CNPq, for the financial support, and Capes, for granting the scholarship.

\section{References}

ALBINO, L.F.T.; FIALHO, F.B.; BELLAVER, C. et al. Estimativas das exigências de energia e proteína para frangas de postura em recria. Pesquisa Agropecuária Brasileira, v.29, p.1625-1629, 1994.

BARTOV, I.; PLAVNIK, I. Moderate excess of dietary protein increases breast meat yield of broiler chicks. Poultry Science, v.77, p.680-688, 1998

BASAGLIA, R.; SAKOMURA, N.K.; RESENDE, K.T. et al. Exigências de proteína para frangas de postura de 1 a 18 semanas de idade. Revista Brasileira de Zootecnia, v.27, n.3, p.556-563, 1998.

BENNETT, C.D.; LEESON, S. Body composition of the broilerbreeder pullets. Poultry Science, v.69, p.715-20, 1990.

CHWALIBOG, A. Factorial estimation of energy requeriment for egg production. Poultry Science, v.71, p.509-515, 1992.

FARRELL, D.J. General principles and assumptions of calorimetry. In: MORRIS, T.R.; FREEMAN, B.M. (Eds.). Energy requirementes of poultry. Edinburgh: British Poultry Science, 1974. p.1-23.

FILARDI, R.S.; SAKOMURA, N.K.; BASAGLIA, R. et al. Equação de predição das exigências de proteína bruta para matrizes pesadas em crescimento. Revista Brasileira de Zootecnia, v.29, n.6, p.2308-2315, 2000 (supl. 2).

FREITAS, A.C.; FUENTES, M.F.F.; FREITAS, E.R. et al. Efeito de níveis de proteína e de energia metabolizável na dieta sobre o desempenho de codornas de postura. Revista Brasileira de Zootecnia, v.34, n.3, p.838-846, 2005.

FULLER, H.L.; DALE, L.M.; SMITH, C.F. Comparison of heat production of chickensmeasured by energy balance and by gaseous exchange. The Journal of Nutrition, v.113, p.1403-1408, 1983.

JORDÃO FILHO, J.; SILVA, J.H.V.; SILVA, C.T. et al. Energy requirement for maintenance and gain for two genotypes of quails housed in different breeding rearing systems. Revista Brasileira de Zootecnia, v.40, n.11, p.2415-2422, 2011

LONGO, F.A; SAKOMURA, N.K; FIGUEIREDO, A.N. et al. Equações de predições das exigências protéicas para frangos de corte. Revista Brasileira de Zootecnia, v.30, n.5, p.1521-1530, 2001.

LONGO, F.A.; SAKOMURA, N.K.; RABELLO, C.B.V. et al. Exigências energéticas para mantença e para o crescimento de frangos de corte. Revista Brasileira de Zootecnia, v.35, n.1, p.119-125, 2006
MARKS, H.L. Carcass composition, feed intake, and feed efficiency following long-term selection for four-week body weight in Japanese quail. Poultry Science, v.72. p.1005-1011, 1993.

MARTIN, P.A; BRADFORD, G.D; GOUS, R.M. A formal method of determining the dietary amino acid requeriments of layingtype pullets during their growing period. British Poultry Science, v.35, p.709-724, 1994

NEME, R.; SAKOMURA, N.K.; FUKAYAMA, E.H. et al. Curvas de crescimento e de deposição dos componentes corporais em aves de postura de diferentes linhagens. Revista Brasileira de Zootecnia, v.35, n.3, p.1091-1100, 2006.

PINTO, R.; FERREIRA, A.S; ALBINO, L.F.T. et al. Níveis de proteína e energia para codornas japonesas em postura. Revista Brasileira de Zootecnia, v.31, n.4, p.1761-1770, 2002.

RABELLO, C.B.V.; SAKOMURA, N.K.; LONGO, F.A. et al. Efeito da temperatura ambiente e do sistema de criação sobre as exigências de energia metabolizável para mantença de aves reprodutoras pesadas. Revista Brasileira de Zootecnia, v.33, n.2, p.382-390, 2004.

RABELLO, C.B.V.; SAKOMURA, N.K.; LONGO, F.A. et al. Equação de predição da exigência de proteína bruta para aves reprodutoras pesadas na fase de produção. Revista Brasileira de Zootecnia, v.31, n.3, p.1204-1213, 2002.

SAKOMURA, N.K.; BASAGLIA, R.; RESENDE, K.T. Modelo para determinar as exigências de proteína para poedeiras. Revista Brasileira de Zootecnia, v.31, n.6, p.2247-2254, 2002.

SAKOMURA, N.K.; BASAGLIA, R.; SÁ-FONTES, C.M.L. et al Modelo para estimar as exigências de energia metabolizável para poedeiras. Revista Brasileira de Zootecnia, v.34, n.2, p.575-583, 2005.

SAKOMURA, N.K.; ROSTAGNO, H.S. Métodos de pesquisa em nutrição de monogástricos. Jaboticabal: FACV/UNESP. 2007, 283p.

SAKOMURA, N.K.; SILVA, R.; COUTO, H.B. et al. Modeling metabolizable energy utilization in broiler breeder pullets. Poultry Science, v.82, p.419-427, 2003.

SCOTT, M.L.; NESHEIM, M.C.; YOUNG, R.J. Nutrition of the chicken. 3.ed. Ithaca: M.L. Scott, 1982. 562p.

SILVA, D.J.; QUEIROZ, A.S. Análise de alimentos: métodos químicos e biológicos. 3.ed. Viçosa, MG: UFV, 2002. 235p.

SILVA, J.H.V.; COSTA, F.GP. Tabelas para codornas japonesas e europeias: tópicos especiais, composição de alimento e exigências nutricionais. 2.ed. Jaboticabal: FUNEP, 2009. 107p.

SILVA, J.H.V.; SILVA, M.B.; JORDÃO FILHO, J. et al. Exigências de mantença e de ganho de proteína e de energia em codornas japonesas (Coturnix coturnix japonica) na fase de 1 a 12 dias de idade. Revista Brasileira de Zootecnia, v.33, n.5, p.1209-1219, 2004a.

SILVA, J.H.V.; SILVA, M.B.; JORDÃO FILHO, J. et al. Exigências de mantença e de ganho em proteína e energia em codornas japonesas (Coturnix coturnix japonica) na fase de 15 a 32 dias. Revista Brasileira de Zootecnia, v.33, n.5, p.1220-1230, 2004b.

SILVA, J.H.V.; JORDÃO FILHO, J.; RIBEIRO, M.L.G. et al. Exigência de proteína bruta para mantença e ganho de peso de codornas japonesas e europeias. In: CONFERÊNCIA APINCO DE CIÊNCIA E TECNOLOGIA AVÍCOLA, 2010, Campinas. Anais... Campinas: FACTA, 2010. p.52.

SPRATT, R.S.; BAYLEY, H.S.; McBRIDE, B.W. et al. Energy metabolism of broiler breeder hens. 1- The partition of dietary energy intake. Poultry Science, v.69, p.1339-1347, 1990.

WOLYNETZ, M.S.; SIBBALD, I.R. Need for comparative slaughter experiments in poultry research. Poultry Science, v.66, p.1961-1972, 1987.

ZHANG, B.; COON, C.N. Nutrient modelling for laying hens. Journal Applied Poultry Research, v.3, p.416-431, 1994. 